\title{
ОСОБЛИВОСТІ АДАПТАЦІЇ ВУГІЛЬНОГО ЗАКОНОДАВСТВА В УМОВАХ ЄВРОІНТЕГРАЦІї
}

Пльохова А. Ю.

У науковій статmі досліджено окремі напрями адаптації вугільного законодавства, пов'язані з євроінтеграційними умовами правового регулювання енергетичних, гірничих, господарських відносин та відносин екологічної безпеки. Проведено аналіз основних законодавчих актів вітчизняного законодавства та директив Європейського Союзу, до сфери яких віднесені певні групи вугільних відносин. Запропоновано конкретні види правовідносин, що потребують змістовного узгодження із приписами європейського законодавства.

Ключові слова: вугільна промисловість, енергетичні корисні копалини, прозорість добувних галузей, енергетична стратегія, видобування вугілля, адаптація законодавства.

В научной статье исследованы отдельные направления адаптации угольного законодательства, связанные с евроинтеграционными условиями правового регулирования энергетических, горных, хозяйственных отношений и отношений экологической безопасности. Проведен анализ основных законодательных актов отечественного законодательства и директив Европейского Союза, в сферу которых отнесены определенные группы угольных отношений. Предложены конкретные виды правоотношений, требующих содержательного согласования с предписаниями европейского законодательства.

Ключевые слова: угольная промышленность, энергетические полезные ископаемые, прозрачность добывающих отраслей, энергетическая стратегия, добыча угля, адаптация законодательства.

Plokhova A. Yu. Features of adaptation of coal legislation in the conditions of European integration

The scientific article explores certain areas of adaptation of coal legislation related to the European integration conditions of legal regulation of energy, mining, economic relations and ecological safety relations.

It has been established that the National Adaptation Program has a significant disadvantage. In many cases, the individual normative legal acts represented in it, especially by-laws, have undergone the following changes: a) have lost force; b) adopted in a new edition; c) have a different name. In accordance with this, they did not fall within the scope of the National Adaptation Program, and therefore restrained this process.

Based on the study conducted, it was revealed that the legal regime of mineral resources in Ukraine does not take into account the area of land under which mining is possible, as well as the economic comparison of land and subsoil use. This situation is a consequence of the absence in Ukraine of a legislative act of the appropriate content, for example, "On the Mineral Resources of Ukraine". Moreover, the distinction among foreign applicants for the use of Ukrainian subsoil is absent in the Ukrainian Code of Subsoil against the backdrop of European integration prospects. The modern concept of subsoil legislation should provide for the "use or abandon" principle in the state mineral and raw policy regarding investors.

The analysis of the main legislative acts of domestic legislation and directives of the European Union is carried out, in the scope of which certain groups of coal relations are classified.
Specific types of legal relations are proposed that require substantive coordination with the requirements of European law, which include such areas: - coal market; - pricing mechanism; - export-import operations; - transformation of coal regions; - industry transparency initiative; - concentration and acquisition of mines; - privatization and attraction of investors; - liquidation of unprofitable mines; - social protection of workers; - tax preferences and rent; - development of atypical coal mines; - use of coal-bearing subsoil resources based on EU principles; - ecological and industrial safety.

Key words: coal industry, energy minerals, transparency of extractive industries, energy strategy, coal mining, adaptation of legislation.

Постановка проблеми та ії актуальність. Сьогодні Європейський Союз (далі - ЄС) та Україна мають спільний кордон і як безпосередні сусіди будуть посилювати свою політичну та економічну взаємопов'язаність. ЄС та Україна сповнені рішучості працювати разом шляхом виконання Плану дій «Україна-Європейський Союз» в рамках Європейської політики сусідства, щоб не допустити появи нових розподільчих ліній в Європі.

Втім, законодавство $\in C$, так само як і геоекономічне, геополітичне становище навколо України, внутрішня ситуація, не $\epsilon$ константами та підвладні змінам у короткостроковій перспективі. Цей фактор не був заздалегідь прописаний у законодавстві України та двосторонніх документах з ЄС, але механізм вдосконалення та адаптації європейських норм все ж таки має місце на засадах взаємних перемовин і компромісів.

Надзвичайно актуальним аспектом євроінтеграційного процесу в Україні залишається питання адаптації національного законодавства до законодавства $€ С$. Відповідно до Угоди про асоціацію між Україною, з однієї сторони, та ЄС, Європейським співтовариством з атомної енергії і їхніми державами-членами, з іншої сторони (далі - УпА) [1], остання взяла на себе зобов'язання вживати заходів для поступового приведення національного законодавства у відповідність із законодавством ЄС у визначених сферах, у тому числі й в енергетичній сфері, зокрема видобуванні енергетичних корисних копалин. Законодавчі засади адаптації визначені Законом України «Про Загальнодержавну програму адаптації законодавства України до законодавства Європейського Союзу» [2], який передбачає серед повноважень Верховної Ради України проведення експертизи внесених всіма суб'єктами права законодавчої ініціативи законопроектів на їх відповідність положенням законодавства $€ C$.

Актуалізує питання євроінтеграційних аспектів адаптації вугільного законодавства й положення Енергостратегії-2035 [3], згідно з якими передбачено, що

(с) Пльохова А. Ю., 2020 
до 2025 р. здебільшого буде завершено реформування енергетичного комплексу України, досягнуто першочергових цільових показників з безпеки та енергоефективності, забезпечено його інноваційне оновлення та інтеграцію з енергетичним сектором $\in C$.

Аналіз останніх досліджень і публікацій. Сьогодні $€ C$ загалом усвідомив можливості для інновацій, нових варіантів економічного розвитку, кращого здоров'я, вищої якості життя, а також пропонує справедливі можливості щодо розвитку всім країнам світу на засадах Паризької кліматичної угоди в 2015 р., про що свідчить пакет законодавчих змін «Чиста енергія для всіх європейців». У пакет закладено амбітні цілі щодо збільшення частки відновлюваних джерел енергії та підвищення енергоефективності. ЄС також включив положення політики щодо низьковуглецевої енергетики до своїх угод про асоціацію із сусідніми країнами, такими як Україна.

Проблемами особливостей адаптації вугільного законодавства в умовах євроінтеграційних процесів переймалася досить чисельна група вітчизняних науковців, що представляють не тільки галузь права i європейського права, а й економіки, енергетики, гірництва, управління тощо. Серед них відзначимо роботи О. Амоші, А. Бардася, О. Бєлозерцева, О. Галушко, В. Геєця, А. Гетьмана, С. Грищака, 3. Драчука, О. Ілларіонова, Р. Кіріна, І. Козьякова, С. Кулицького, І. Павленко, Г. Пилипенко, Л. Рассуждай, Т. Решетілової, В. Саллі та інших науковців.

Розглядаючи євроінтеграційні перспективи гірничого законодавства, автори [4, с. 138] звернули увагу, що окрема стаття УпА обумовлює появу новел за перспективної кодифікації вітчизняного вугільного законодавства (ст. 339), в якій, зокрема, зазначається, що сторони обмінюються інформацією і досвідом, а також надають відповідну підтримку процесу регуляторних реформ, який включає реструктуризацію вугільного сектору (енергетичного, коксованого та бурого вугілля) 3 метою: а) підвищення його конкурентоспроможності; б) безпеки шахт і гірників; в) послаблення негативного впливу на навколишнє середовище, при цьому враховуючи регіональний та соціальний вплив. 3 метою підвищення ефективності, конкурентоспроможності та стабільності процес реструктуризації має охоплювати всі етапи вугільного виробництва, зокрема: 1) видобуток, виробництво і збагачення вугільної продукції; 2) оброблення й утилізації відходів вугільного виробництва та їх спалювання.

Водночас, як відмічають учені-економісти [5, с. 37], Україна належить до дванадцяти країн світу з найбільшими обсягами видобутку вугілля, але значно поступається більшості з них як за рівнем, так і за динамікою технічно-економічних показників вуглевидобування внаслідок складних природних умов і невисокого технічного рівня.

С. Кулицький звертає увагу на те, що наслідком вичерпання найзручніших для видобутку покладів вугілля на Донбасі, як основному регіоні його видобування в Україні, стало загальне скорочення виробництва вугілля в нашій державі. Причому за умов ринкової трансформації української економіки, коли обсяги видобутку вугілля в Україні почали визначатися ринковим попитом на нього за одночасної конкуренції постачальників цього товару, навіть контроль над вітчиз- няною законодавчою та виконавчою владою у нашій державі з боку вихідців із Донбасу не зміг радикально змінити визначальну роль ринкового попиту на динаміку обсягів виробництва вугілля в Україні [6, с. 37].

Метою статті $\epsilon$ дослідження та аналіз окремих напрямів адаптації вугільного законодавства, пов'язаних $з$ євроінтеграційними умовами правового регулювання енергетичних, гірничих, господарських відносин та відносин екологічної безпеки.

Виклад основного матеріалу. Розширення дає можливість для України та $Є С$ розвивати якомога тісніші відносини, що виходитимуть поза рамки співробітництва до поступової економічної інтеграції та поглиблення політичного співробітництва. ЄС та Україна сповнені рішучості посилити свої відносини та сприяти утвердженню стабільності, безпеки і добробуту. Такий підхід заснований на спільних цінностях, спільній власності та диференціації. Це сприятиме подальшому зміцненню нашого стратегічного партнерства.

Як заначено в Енергостратегії-2035 [3], до 2020 р. має бути створено ринок вугільної продукції, а власне реструктуризація вугільної промисловості супроводжуватиметься комплексом заходів з пом'якшення соціальних та екологічних наслідків ліквідації/консервації вугільних шахт та соціальної реконверсії регіонів закриття шахт відповідно до найкращих європейських практик.

Загальне становище суб'єктів вугледобувної промисловості, залежно від форми власності, можна оцінити так. Недержавний (приватний) сектор розвивається в руслі світових тенденцій і завдяки більш сприятливим природним умовам, своєчасному інвестуванню, більш високому рівню менеджменту хоча й поступається провідним вугільним галузям світу, але $\epsilon$ рентабельним і перспективним. Натомість державний сектор, який має більш складні природні й виробничі умови, звужується і деградує внаслідок приватизації, передачі в оренду та концесію кращих підприємств, а також неефективного господарювання, $\epsilon$ збитковим, обтяженим великими боргами, і його стан слід оцінювати як кризовий.

Одним із важливих напрямів узгодження національного та європейського законодавства $є$ економіко-правові відносини, пов'язані з видобуванням та обігом вугільної продукції. Ще у 2008 р. О.Ю. Ілларіонов звернув увагу на те, що законодавство України зовсім не регулює особливості здійснення експортно-імпортних операцій щодо вугільної продукції. За прогнозами на 2008 р. Україна буде змушена імпортувати 10-12 млн. тонн коксівного вугілля. Пов'язані з цим проблеми демпінгу (й антидемпінгу) і нетарифних обмежень також $\epsilon$ «білою плямою» в законодавстві попри те, що в $\in C$ це $\epsilon$ одним із найурегульованіших питань [7, с. 95].

На думку Генерального секретаря Європейської асоціації вугілля та лігніту «Euracoal» Б. Ріккетса [8], введення імпортного паритету під час ціноутворення на вугілля було єдино вірним рішенням для України, а прив'язка до індексу API2 (порт Роттердам) - абсолютно коректна. 31 липня 2019 р. у зв'язку з введенням в Україні нового ринку електроенергії дія формули «Роттердам +» припинилася. Той таки функціонер підкреслив важливість самостійного видобутку вугілля, адже Україна має видобувати своє власне вугілля. Доступ до вугілля зі східної частини країни $€$ головним 
пріоритетом, і це питання має вирішуватись дипломатичними шляхами. Можливо, зараз варто заявити про ці ресурси на підставі наявної потреби, а Європейська Комісія повинна виступити посередником між двома сторонами конфлікту для досягнення прагматичних домовленостей за рухом і розподілом вугілля.

Розглядаючи відносини у сфері реалізації вугільної продукції, О.О. Владиченко дійшов висновку [9, с. 115], що коло суб'єктів господарювання, які мають реалізувати вугільну продукцію, необхідно обмежити вугільними, вуглепереробними та коксохімічними підприємствами, котрі безпосередньо виробляють цю продукцію, а також вузькоспеціалізованими товарними біржами, створеними цими виробниками, які здатні узгодити попит та пропозицію на цю продукцію та організувати iï реалізацію, з метою стабілізації ціни на цей біржовий товар. Запропоноване вище коло суб'єктів господарювання у сфері реалізації вугільної продукції доцільно визначити в законодавстві з метою виключення посередників та формування реальної ціни на цей вітчизняний енергоносій як альтернативний газу.

Втім, як справедливо зазначає О.Ю. Ілларіонов [10, с. 18], законодавство України, яке регулювало умови господарювання, функціонування вугільної промисловості, організацію ринку вугільної продукції, забезпечення експортно-імпортних (переважно експортних) операцій тощо, під впливом різних факторів адаптовувалося до відповідників ЄС не прозоро. Цей процес до 2012 р. відбувався в рамках реалізації положень Загальнодержавної програми [2], яка не позбавлена одного суттєвого недоліку. У багатьох випадках вміщені в ній нормативно-правові акти (далі - НПА), особливо підзаконні, зазнали таких змін: а) втратили чинність; б) прийняті в новій редакції; в) мають іншу назву. Відповідно до цього вони не підпадали під дію зазначеної Загальнодержавної програми.

Також слід звернути увагу на той факт, що з моменту прийняття УпА вона значно застаріла, в тому числі й Додаток XXVII, у зв'язку з динамічним розвитком енергетичного законодавства ЄС. На виправлення ситуації, що склалася, спрямований відповідний законодавчий акт [11], яким вносяться зміни та доповнення до згаданого Додатку, але вугільної промисловості ці зміни прямо не торкнулися. Тому доцільним убачається проведення ревізії імплементації положень законодавства ЄC в законодавство, що забезпечує функціонування вугільної промисловості, ринку вугільної продукції тощо. Останній разом з умовами постачання вугілля певною мірою впливає і на ринок електричної енергії, а отже, від врегулювання даного виду вугільних відносин залежить i виконання положень Додатку щодо виробництва та розподілу електроенергії. Необхідність посилення євроінтеграції, інтенсифікації проведення економічних реформ спонукала до прийняття Указу Президента України [12], в якому в зовнішньополітичній сфері до кінця 2020 р. пропонується розроблення з урахуванням поточного стану співробітництва пропозицій для перегляду виконання УпА, зокрема й у сфері енергетики.

Оскільки вугілля відноситься до корисних копалин загальнодержавного, стратегічного значення, логічним буде також аналіз проблем адаптації гірничого законодавства. Одним з основних НПА останнього $є$ Гірничий закон України, що визначає правові та організаційні засади проведення гірничих робіт, забезпечення протиаварійного захисту гірничих підприємств, установ та організацій. Отже, цей закон регулює види відносин, що безпосередньо відносяться до вугільної галузі: 1) загальні положення; 2) державну політику у сфері регулювання гірничих відносин; 3) підготовку до проведення гірничих робіт і видобутку корисних копалин; 4) експлуатацію гірничих підприємств; 5) протиаварійний захист і безпеку проведення гірничих робіт; 6) особливості екологічної безпеки гірничих робіт; 7) особливості умов праці в гірничодобувній промисловості; 8) припинення діяльності гірничих підприємств; 9) відповідальність за порушення гірничого законодавства; 10) міжнародні відносини.

Натомість правовий режим мінеральних ресурсів в Україні не враховує ані площу земель, під якими можливе здійснення гірничих робіт, ані економічне порівняння земле- та надрокористування. Подібна ситуація $\epsilon$ наслідком відсутності в Україні законодавчого акту відповідного змісту, наприклад «Про мінеральні ресурси України». Крім того, на тлі перспектив європейської інтеграції в Кодексі України про надра відсутнє розмежування серед іноземних претендентів на користування українськими надрами. Концепція нового акту законодавства про надра повинна передбачати раціональне використання надр для видобування корисних копалини, а також застосування принципу «використовуй або відмовся» в державній мінерально-сировинній політиці відносно інвесторів.

Приклад сусідньої Польщі, де ці види відносини врегульовані Статутом гірничим та геологічним, свідчить і про необхідність імплементації основних правових норм $\in C$ у цій сфері. Подібними і такими, що, на жаль, чинне українське законодавство не враховує або враховує неналежним чином, пропонується визнати такі, як:

- Директива Ради 92/104/ЄЕС від 3 грудня 1992 року щодо мінімальних вимог до підвищення рівня безпеки та охорони здоров'я працівників гірничо-видобувної галузі, які працюють на поверхні та під землею (дванадцята індивідуальна Директива у значенні статті 16(1) Директиви 89/391/ЄЕС) [13];

Директива Ради 92/91/ЄЕС від 3 листопада 1992 року стосовно мінімальних вимог до підвищення рівня безпеки та охорони здоров'я працівників у гірничо-видобувній (шляхом буріння) галузі (одинадцята індивідуальна Директива у значенні статті 16(1) Директиви 89/391/ЄЕС) [14];

Директива Європейського парламенту та Ради 94/22/ЄС від 30 травня 1994 року про умови надання та використання дозволів на розвідку, розробку та видобуток вуглеводнів [15];

- Директива Ради 1999/31/ЄС від 26 квітня 1999 року щодо захоронення відходів [16];

Рішення Ради 2003/33/ЄС від 19 грудня 2002 р., що встановлює критерії та процедури прийняття відходів на полігони у відповідності до ст. 16 та додатку II Директиви 1999/31/ЄС.

Надзвичайно важливим аспектом адаптації вугільного законодавства $\epsilon$ його еколого-правовий складник, який не в останню чергу зумовлений економічним складником. Зрозуміло, першопричина «екологізації» сфери видобутку вугілля дійсно має економічний характер: зростання залежності Європи від імпорту вуглеводневої сировини. Продовжуючи йти шляхом «біз- 
нес, як звичайно», енергетична залежність Європи від імпорту з 50\% загального споживання енергії зросте до 65\% у 2030 р. Залежність від імпорту газу, за експертними оцінками, зросте з 57\% до $84 \%$, а нафти - з $82 \%$ до 93\%. Така тенденція несе в собі серйозні політичні та економічні ризики. Крім того, стрімке зростання нафтогазової галузі, потреби в цих ресурсах не $\epsilon$ оптимальним варіантом розвитку енергетики з точки зору соціально-екологічних інтересів суспільства, цінність яких різко зросла в останні десятиліття. Вихід із подібної ситуації в межах енергетичної політики $Є С$ бачиться у використанні поновлюваних джерел енергії, розвитку передових технологій і підвищення енергоефективності. Вирішення цих завдань має важливий соціально-екологічний «складник» - зниження навантаження на природні ресурси, поліпшення якості навколишнього середовища.

Крім того, в довгостроковій перспективі важливим завданням України $є$ переведення економіки на шлях низьковуглецевого розвитку. Для цього необхідно розробити Концепцію декарбонізації економіки України, 3 поступовим скороченням використання вугілля для виробництва енергії. А встановлення податків та зборів за викиди шкідливих речовин, вилучення породи на поверхню, а також штрафів за займання відвалів сприятиме зменшенню негативного впливу вугледобувних підприємств на довкілля.

Наступна група відносин, яка також потребує аналізу в євроінтеграційному аспекті адаптації вугільного законодавства, $є$ відносини із забезпечення ініціативи прозорості видобувних галузей (далі - ІПВГ), до яких відноситься й вугледобувна промисловість.

Розглядаючи проект закону в цій сфері, Комітет Верховної Ради України з питань європейської інтеграції зауважив, що, по-перше, за предметом правового регулювання він належить до сфери законодавства про компанії, податків та енергетики, які відповідно до закону [2] належать до пріоритетних сфер, в яких здійснюється адаптація законодавства України до законодавства ЄС. По-друге, законопроект не суперечить праву ЄC, а правовідносини, що належать до сфери правового регулювання проекту закону, регулюються також низкою директив ЄС [18].

Нарешті, у затвердженому Плані заходів Міненерговугілля з виконання УаП (найменування завдання: 842. Удосконалення механізму розкриття даних та обміну інформацією щодо видобувних галузей; положення Угоди: статті 381-382) було передбачено: 1) розроблення та подання на розгляд Кабінету Міністрів України законопроекту про забезпечення прозорості у видобувних галузях; 2) опрацювання законопроекту з експертами $Є C$; 3) забезпечення супроводження розгляду Верховною Радою України законопроекту [19].

На цей раз парламент України досить оперативно підтримав пропозицію уряду, прийнявши закон, що визначає правові засади регулювання та організації збирання, розкриття та поширення інформації з метою забезпечення прозорості та запобігання корупції у видобувних галузях України [20]. Зазначений закон спрямований на виконання міжнародних зобов'язань України у зв'язку з приєднанням до ІПВГ, а також на імплементацію актів законодавства Європейського Союзу в частині підвищення прозорості господарської діяльності у видобувних галузях, а саме:
1) Директиви 2013/34/ЄС Європейського Парламенту і Ради про щорічну фінансову звітність, консолідовану фінансову звітність та пов'язані з ними звіти певних типів компаній, що вносить зміни до Директиви 2006/43/ЄС Європейського Парламенту і Ради та скасовує Директиву Ради 78/660/ЄЕС і 83/349/ЄЕС;

2) Директиви 2013/50/ЄС Європейського Парламенту і Ради, що вносить зміни до Директиви 2004/109/ЄС Європейського Парламенту і Ради про гармонізацію вимог до прозорості стосовно інформації про емітентів, чиї цінні папери допущені до торгів на регульованому ринку;

3) Директиви 2003/71/ЄС Європейського Парламенту і Ради про проспект торгів, що публікується у випадках, коли цінні папери пропонуються для продажу приватним особам або допущені до торгів;

4) Директиви Комісії 2007/14/€С, що встановлює детальні правила для імплементації окремих положень Директиви 2004/109/€С.

Як зазначають фахівці Інституту бюджету та соціально-економічних досліджень, ІПВГ не $\epsilon$ усталеним інструментом оцінки платежів і доходів, а продовжує динамічно розвиватися. Включення у звітність контекстної інформації дозволяє глибше охопити проблематику функціонування видобувного сектору, розширити можливості вивчення тенденцій його розвитку та пропонувати відповідні корективи. Ініціатива також спрямована на поширення форм участі громадськості у формуванні планів розвитку на місцевому та регіональному рівнях [21].

Виконуючи положення УпА, вже наступного дня після ii ухвалення розпорядженням уряду від 17.09.2014 р. № 847-р про імплементацію УпА було передбачено:

1) розроблення та подання на розгляд Кабінету Міністрів України проектів НПА з метою імплементації положень Директиви 94/22/ЄС Європейського Парламенту та Ради від 30 травня 1994 р. про умови надання та використання дозволів на пошук, розвідування та видобуток вуглеводнів;

2) розроблення та подання на розгляд Кабінету Міністрів України проектів НПА з метою імплементації положень Директиви 2006/21/ЄС Європейського Парламенту та Ради від 15 березня 2006 р. про управління відходами видобувної промисловості та внесення змін і доповнень до Директиви 2004/35/ЄС (ст. ст. 360-363, 365, 366, додаток XXX);

3) розроблення, прийняття та впровадження НПА про мінімальні вимоги для поліпшення безпеки та захисту здоров'я працівників у видобувних галузях, що використовують буріння (здоров'я і безпека праці);

4) розроблення, прийняття та впровадження НПА про мінімальні вимоги до поліпшення безпеки та захисту здоров'я працівників видобувних підприємств з підземним і відкритим способами видобування (здоров'я і безпека праці) (ст. ст. 420, 424, додаток XL).

Слід зазначити також, що основним НПА, предмет регулювання якого збігається 3 предметом регулювання Правил безпеки у вугільних шахтах (затверджені наказом Державного комітету України з промислової безпеки, охорони праці та гірничого нагляду від 22.03.2010 р. № 62), $\epsilon$ Рішення Ради міністрів ЄСВС щодо компетенції та правил процедури Комісії з безпеки на шахтах [22], а також Рішення від 11.03.1965 р. представників урядів держав-членів, що зустрілися в рамках спеціальної ради міністрів відносно внесення змін 


\section{Проблеми \\ екологічного законодавства}

до Рішення від 9 липня 1957 р. щодо компетенції та правил процедури Комісії з безпеки на шахтах [23].

Досить важними євроінтеграційними аспектами вугільного законодавства слід вважати також і такі групи відносин, як:

1) забезпечення платоспроможності державних вугледобувних підприємств, зокрема відносин, пов'язаних з їх банкрутством та відповідними заходами виконавчого провадження, що розглядається як створення умов для забезпечення державної політики у вугільній галузі [24];

2) порядок використання коштів, передбачених у державному бюджеті для реструктуризації вугільної галузі [25];

3) трансформація вугільних регіонів України [26].

Отже, перед Україною в адаптаційному напрямі поставлені цілком окреслені завдання не тільки відносно енергетичного, вугільного. гірничого господарського законодавства, а й законодавства про видобувні відходи, а також законодавства про безпеку праці та захист здоров'я працівників видобувних галузей, які, безумовно, слід відобразити як у спеціальних законодавчих актах, так і в кодифікованому акті законодавства про надра.

Висновки. Проблема адаптації вугільного законодавства в умовах євроінтеграції, що триває, $є$ комплексною і багатогранною, а отже, необхідним кроком для системних змін у цьому нормативно-правовому угрупуванні $\epsilon$ адаптація та гармонізація таких відносин, як:

1) господарські відносини у сфері створення сталого ринку вугільної продукції, прозорого механізму ціноутворення й особливостей здійснення експортно-імпортних операцій щодо вугільної продукції, відносини трансформації вугільних регіонів України та ініціативи прозорості видобувних галузей;

2) конкурентні та антимонопольні відносини щодо здійснення господарської діяльності у вугільній промисловості, в тому числі особливостей концентрації та поглинання, вирішення конкурентних спорів у галузі, а також відносин взаємозв'язку собівартості й ринкової ціни як фактору підвищення конкурентоздатності вугільної продукції; відносини у сфері збереження балансу впливів на ринку та створення умов для конкурентного ціноутворення;

3) приватизаційні та інвестиційні відносини - ефективна приватизація активів державних вугільних підприємств та залучення інвесторів до їх реструктуризації та модернізації; окремо необхідно врегулювати питання процедури та особливостей приватизації у вугільній галузі шляхом розроблення нових програмних актів щодо ліквідації збиткових, нерентабельних, із забезпеченням соціального захисту працівників та приватизації тих вугільних шахт, які або прибуткові та механізовані, або потенційно прибуткові за умови залучення відповідних інвестицій та технологій;

4) податкові та фінансові відносини - скасування податкових преференцій та приведення рентної плати у відповідність до ренти на видобуток газу; адаптація порядку використання коштів, передбачених у державному бюджеті для реструктуризації вугільної галузі, відносини платоспроможності державних вугледобувних підприємств;

5) енергетичні відносини - розроблення і прийняття необхідної нормативної бази для можливого переходу на опалення за рахунок електричних котлів за умов економічної доцільності, стабільності мережі та достатності постачання відповідно до умов, необхідних для приєднання до EOTSO-E;

6) надрові, гірничі й вугільні відносини - вдосконалення нормативного забезпечення процесу ліквідації, в тому числі й фізичної, вугільних підприємств, розвиток нетипових вугільних шахт; набуття права користування вугленосними надрами на засадах принципів ЄС; подальше реформування та систематизація вугільного законодавства, спрямовані на розвиток раціонального господарювання та вугільного підприємництва;

7) екологічні відносини - поступова відмова від вугільних ТЕЦ і ТЕС, збільшення частки відновлюваних джерел енергії в електроенергетиці до 25\% до 2035 р. та імплементація європейського законодавства у сферах енергоефективності та захисту клімату задля зменшення шкідливих викидів, захисту довкілля і здоров'я громадян, а також зниження енергетичної залежності держави.

\section{Література}

1. Про ратифікацію Угоди про асоціацію між Україною, з однієї сторони, та Європейським Союзом, Європейським співтовариством з атомної енергії і їхніми державами-членами, з іншої сторони : Закон України від 16 вересня 2014 р. № 1678-VII. Офіційний вісник України. 2014. 26.09. № 75. T. 1. С. 82. Ст. 2125.

2. Про Загальнодержавну програму адаптації законодавства України до законодавства Європейського Союзу : Закон України від 18 березня 2004 р. № 1629-IV. URL: https://zakon.rada.gov.ua/laws/show/1629-15\#Text

3. Про схвалення Енергетичної стратегії України на період до 2035 року «Безпека, енергоефективність, конкурентоспроможність» : розпорядження Кабінету Міністрів України від 18 серпня 2017 р. № 605-р. Урядовий кур'єр. 2017. 08.09. № 167.

4. Кірін Р.С., Грищак С.В., Хряпінський П.В. Євроінтеграційні перспективи гірничого законодавства України. Гуманітарний журнал. 2014. № 3-4. С. 132-141.

5. Амоша О.І., Стариченко Л.Л., Череватський Д.Ю. Стан, основні проблеми і перспективи вугільної промисловості України. Наукова доповідь. ; НАНУ, Інститут економіки промисловості. Донецьк, 2013. 44 с.

6. Кулицький С. Вугільна промисловість України: сучасний стан і проблеми розвитку. Україна: події, факmu, коментарі. 2016. № 17. С. 37-44.

7. Ілларіонов О.Ю. Адаптація вугільного законодавства України до норм Європейського Союзу. Економіка та право. 2008. № 2. С. 90-97.

8. Інформаційно-аналітичне дослідження стану паливно-енергетичного комплексу України «Енергоінформ Информэнерго» № 570. URL: https://www.ntseu.net.ua/ docs/review570-201909.pdf

9. Владиченко О. Законодавче визначення кола суб'єктів господарювання у сфері реалізації вугільної продукції. Вісник Київського національного університету імені Тараса Шевченка. Юридичні науки. 2012. Вип. 91. С. 113-116.

10. Ілларіонов О.Ю. Модернізація положень Угоди про асоціацію України з Європейським Союзом у сфері енергетики (на прикладі вугільної промисловості). Сталий розвиток як платформа для євроінтеграції України : Матеріали міжнародної конференції (Київ, 8 листопада 2019 року) / за заг. ред. проф. О.О. Романовського, с.н.с. Л.В. Жарової Київ ; Українсько-американський університет Конкордія, 2019103 с. С. 18-20. 


\section{Проблеми екологічного законодавства}

11. Про Рішення Ради асоціації між Україною та ЄС про внесення змін і доповнень до Додатка XXVII до Угоди про асоціацію між Україною, з однієї сторони, та Європейським Союзом, Європейським співтовариством з атомної енергії їніми державами-членами, з іншої сторони : Закон України від 6 червня 2019 р. № 2739-VIII. Офіційний вісник України. 2019. 12.07. № 52. С. 9. Ст. 1783.

12. Про невідкладні заходи з проведення реформ та зміцнення держави : Указ Президента України від 8 листопада 2019 р. № 837/2019. Офіційний вісник Президента України. 2019. 19.11. № 24. С. 29. Ст. 1038.

13. Council Directive 92/104/EEC of 3 December 1992 on the minimum requirements for improving the safety and health protection of workers in surface and underground mineral-extracting industries (twelfth individual Directive within the meaning of Article 16 (1) of Directive 89/391/ EEC) // OB L 404 31.12.92 C. 10.

14. Council Directive $92 / 91 /$ EEC of 3 November 1992 concerning the minimum requirements for improving the safety and health protection of workers in the mineralextracting industries through drilling (eleventh individual Directive within the meaning of Article 16 (1) of Directive 89/391/EEC) // OB L 348 28.11.92 C. 9.

15. Directive $94 / 22 / E C$ of the European Parliament and of the Council of 30 May 1994 on the conditions for granting and using authorizations for the prospection, exploration and production of hydrocarbons // OB L 164, 30.06.94 C. 3.

16. Council Directive 1999/31/EC of 26 April 1999 on the landfill of waste // OB L 182, 16.07.99 C. 1.

17. Gryschak S., Kirin R. Legal regime of energy resources of European Union: ecological aspect. Progressive Technologies of Coal, Coalbed Methane, and Ores Mining Editors / V. Bondarenko, I. Kovalevs'ka, K. Ganushevych (eds). Taylor \& Francis Group, London. 521 p. P. 357-360.

18. Висновок Комітету Верховної Ради України з питань європейської інтеграції від 20.05.2015 p. URL: http:// w1.c1.rada.gov.ua/pls/zweb2/webproc4_1?pf3511=54706

19. Про виконання Угоди про асоціацію : наказ Міністерства енергетики та вугільної промисловості України від
02.04.2018 p. № 196. URL: https://zakon.rada.gov.ua/rada/ show/v0196732-18

20. Про забезпечення прозорості у видобувних галузях : Закон України від 18.09.2018 р. № 2545-VII.I. URL: https://zakon.rada.gov.ua/laws/show/2545-19\#Text

21. Впровадження Ініціативи прозорості видобувних галузей в Україні : практичний посібник / за заг. ред. В.В. Зубенка ; ІБСЕД, проект «Зміцнення місцевої фінансової ініціативи (ЗМФІ-ІІ) впровадження». Київ, 2016. 64 c.

22. ECSC Council of Ministers Decision concerning the terms of reference and rules of procedure of the Mines Safety Commission) // OB 028. - 31.08.57. - C. 487.

23. Decision of 11 March 1965 of the Representatives of the Governments of the Member States, meeting within the Special Council of Ministers, amending the Decision of 9 July 1957 concerning the terms of reference and rules of procedure of the Mines Safety Commission) // OB P 046. 22.03.65. C. 98.

24. Про внесення змін до деяких законів України щодо створення умов для забезпечення державної політики у вугільній галузі : Закон України від 18 грудня 2018 р. № 2658-VIII. Офіційний вісник України. 2019. 29.01. № 8. С. 12. Ст. 256.

25. Про затвердження Порядку використання коштів, передбачених у державному бюджеті для реструктуризації вугільної галузі : постанова Кабінету Міністрів України від 23 січня 2019 р. № 80. URL: https://zakon.rada.gov.ua/ laws/show/80-2019-\%D0\%BF\#n8

26. Про утворення Координаційного центру з питань трансформації вугільних регіонів України : постанова Кабінету Міністрів України від 13 травня 2020 р. № 391. Офіційний вісник України. 2020. 05.06. № 43. С. 80. С. 1381.

Пльохова А. Ю., аспірантка кафедри екологічного права Національного юридичного університету імені Ярослава Мудрого 